\title{
Feminist responses to same sex relationship recognition
}

Book or Report Section

Accepted Version

Auchmuty, R. (2020) Feminist responses to same sex relationship recognition. In: Ashford, C. and Maine, A. (eds.) Research Handbook on Gender, Sexuality and the Law. Edward Elgar, Cheltenham, pp. 163-179. ISBN 9781788111140 Available at http://centaur.reading.ac.uk/87349/

It is advisable to refer to the publisher's version if you intend to cite from the work. See Guidance on citing.

Publisher: Edward Elgar

All outputs in CentAUR are protected by Intellectual Property Rights law, including copyright law. Copyright and IPR is retained by the creators or other copyright holders. Terms and conditions for use of this material are defined in the End User Agreement. 


\section{www.reading.ac.uk/centaur}

\section{CentAUR}

Central Archive at the University of Reading

Reading's research outputs online 


\section{FEMINIST RESPONSES TO SAME-SEX RELATIONSHIP RECOGNITION}

\section{Rosemary Auchmuty}

This chapter surveys feminist responses to the enactment of formal recognition of same-sex relationships in the Civil Partnership Act 2004 and the Marriage (Same Sex Couples) Act 2013. Responses are grouped into four categories: celebrations of equal access to rights and privileges; celebrations of acceptance and full citizenship; critiques of state intervention and the institution of marriage; and claims (and responses to those claims) that same-sex marriage will be better than opposite-sex marriage because it is more equal and less gendered, and could bring about the positive transformation of the institution.

Keywords: feminism; marriage; civil partnership; rights; gender.

That same-sex relationships existed and deserved legal protection was recognised long before the enactment of the first formal regulation of such relationships in the UK in the Civil Partnership Act 2004, which applies to the whole UK, followed by the Marriage (Same Sex Couples) Act 2013, which applies to England and Wales. ${ }^{1}$ For example, Barclay's Bank v O'Brien [1994] 1AC 180 offered legal protection for same-sex victims of undue influence, Ghaidan v Godin-Mendoza [2004] UKHL 30 accepted same-sex partners for the purposes of tenancy succession, and pension providers like my own allowed contributors to nominate a same-sex partner to receive 'widow's' benefits. Forms routinely provided space for 'partners' without any assumptions about legal status or gender. Hospitals allowed samesex partners as next of kin, though they sometimes had difficulty identifying them, and some lesbians and gay men experienced discrimination when competing with biological family members. In this chapter, however, I intend to use the term 'relationship recognition' to denote the formal relationship regulation introduced by the two Acts above, because that is how it tends to be perceived today - as a welcome accession by lesbian and gay couples to the privileged status from which they were formerly excluded.

Feminist critics do not see the law in quite this way, of course. As Claudia Card explains, "'Recognition" has a positive ring. Yet what is at stake here is not just recognition but regulation by the state, including the power to determine what counts as a marriage'. ${ }^{2}$ But neither do feminists deny the positive effect that legal recognition has had on public

\footnotetext{
${ }^{1}$ In Scotland, same-sex marriage was introduced in the Marriage and Civil Partnership (Sctland) Act 2014. There is no same-sex marriage in Northern Ireland.

${ }^{2}$ Claudia Card, 'Gay Divorce: Thoughts on the Legal Regulation of Marriage' (2007) 22 Hypatia 24, 24
} 
perceptions of lesbians and gay men and their relationships. 'Relationship regulation' has a punitive and constraining sound, but civil partnerships and same-sex marriage are not always or solely like that. So 'relationship recognition' is better, provided we remember that recognition is generally good, while regulation is a two-edged sword. The chapter will focus on the English situation, as informed by influential North American commentaries which share some similar perspectives, though the law and context are different.

\section{EQUALITY}

The most common response to the legal recognition of same-sex relationships in the Civil Partnership Act 2004 and the Marriage (Same Sex Couples) Act 2013 was a celebratory one: at last gays and lesbians enjoyed equal rights with heterosexuals in respect of their couple relationships. The rights were not, in fact, entirely equal since neither civil partnership nor same-sex marriage (which are legally identical) is precisely the same as traditional marriage but, since the British public has always been supremely indifferent to legal niceties until they come up against them themselves (for example, on divorce), this hardly mattered: as far as most people were concerned lesbian and gay couples now enjoyed the same status, rights and responsibilities as heterosexual couples.

There are three main reasons why this focus on equality was the dominant one. The first and most obvious is that our anti-discrimination legislation (Equality Act 2010 and Article 14 of the Human Rights Act 1998) is founded on the principle of difference from or disadvantage compared to another group (not necessarily the dominant one). Equality and non-discrimination are therefore concepts that twenty-first-century citizens understand and accept as incontrovertibly right. The second reason is that the movement for same-sex relationship recognition was largely driven by men, ${ }^{3}$ for whom formal equality has rarely presented the shortcomings that feminists had long identified and struggled against. Politically-motivated lesbians were more concerned at the time with gender-based issues such as custody of children and violence against women. Moreover, gay men were more likely than lesbians to seek marriage rights to protect their wealth (men being generally

\footnotetext{
${ }^{3}$ Susan S. Boyd, "'Marriage is more than just a piece of paper": Feminist Critiques of Same Sex Marriage' (2013) 8 National Taiwan University Law Review 263, 283
} 
richer than women) or to sponsor a partner to enter the country (gay men being more likely to have a dependent, foreign-born partner than lesbians). ${ }^{4}$

A third reason was that the movement for same-sex marriage was not home-grown, and rather took British feminists by surprise. The dominant push came from the United States where the focus on rights and equality was a more natural fit, since its constitution is framed in terms of rights. In the US, too, the movers and shakers were overwhelmingly male,${ }^{5}$ and many came from a political position diametrically opposed to that of lesbian feminists, emphasising the unthreatening similarities between homosexuals and heterosexuals, rather than any radical differences. ${ }^{6}$

The equality arguments were not simply about equality of status. They also encompassed equal access to the legal and financial benefits that marriage brought or was imagined to bring. These differ greatly from jurisdiction to jurisdiction. In the UK they are actually quite limited, the political trajectory up to the turn of the century being to accommodate to the decline in marriage and rise in unmarried cohabitation by encompassing unmarried cohabitants in most state protections and responsibilities attaching to married couples. In the UK, therefore, there was an observable lack of understanding of, or even interest in, the actual legal consequences of civil partnership or marriage - an ignorance that sometimes led to astonishment when these became obvious, as on dissolution. ${ }^{7}$ In the United States, however, marriage makes a much greater legal and financial difference, the most significant feature being the ability of a married individual to add his or her spouse and family to their healthcare plan. Many of the American lesbians and gay men Kimberly D. Richman interviewed in License to Wed: What legal marriage means to same-sex couples (New York University Press, 2014) mentioned equal access to

\footnotetext{
${ }^{4}$ Rosemary Auchmuty, 'Dissolution or disillusion: the unravelling of civil partnerships' in Nicola Barker and Daniel Monk (eds), From Civil Partnership to Same-Sex Marriage: Interdisciplinary reflections (Routledge 2015) 202

${ }^{5}$ See, for example, Robert M Baird \& Stuart E Rosenbaum, eds. Same-Sex Marriage: The Moral and Legal Debate (Amherst: Prometheus, 1997), Mark Strasser, Legally Wed: SameSex Marriage and the Constitution (Cornell UP 1997), Andrew Sullivan ed. Same-Sex Marriage: Pro and Con (NY: Vintage books, 1997), William N. Eskridge Jr, Equality Practice: Civil Unions and the Future of Gay Rights (NY: Routledge, 2002) ${ }^{6}$ Andrew Sullivan, Virtually Normal: an argument about homosexuality (NY: Knopf 1995). ${ }^{7}$ Rosemary Auchmuty, 'The Experience of Civil Partnership Dissolution: Not "just like divorce"' (2016) 38 Journal of Social Welfare and Family Law 152
} 
financial and legal benefits, and were able to point to particular provisions such as spousal rights to health insurance. Kentucky law professor Joan Callahan concluded in a 2009 article, after receiving a diagnosis of Stage 4 cancer, that 'as long as the institution of marriage remains the only way for people like me to provide crucial rights and goods for my family, it is simply intolerable that the state supports my exclusion' ${ }^{8}$ Using the classic language of comparison, she argued that real-life needs like hers should be prioritised over longer-term strategies like fighting for better access to healthcare benefits for everyone.

\section{CITIZENSHIP}

We should never forget just how far we have travelled from the days - within the lifetimes of many of us - when homosexuals were cast out from society, forced to live in the closet, having their lives destroyed when outed. When terms like 'dignity' and 'respect' are so freely invoked today to justify much less momentous reforms, we should recall this terrible history of homosexual oppression, which still goes on in many places. This explains why, for many lesbians and gay men, equality was not actually the first reason to seek and celebrate legal recognition of their relationships. Before and above that came the perception that, after decades - indeed, centuries - of being treated as unnatural, immoral, or illegal, they were now accepted and deserving. As the magazine of the British lesbian and gay lobby group Stonewall proclaimed when the Civil Partnership Act came into force in December 2005:

It will acknowledge the existence and validity of same-sex relationships for the first time and allow those relationships to be publicly celebrated. It will also send a powerful signal to young people who are growing up gay that when they grow up their relationships will be treated in the same way as their straight friends. ${ }^{9}$

For lesbians who, though never suffering the full force of the criminal law as gay men had done before 1967, relationship recognition provided an opportunity to step out of the protective but restrictive cloak of invisibility, ${ }^{10}$ felt most keenly after the enactment of section 28 of the Local Government Act 1988 which prohibited to 'promotion' of

\footnotetext{
${ }^{8}$ Joan Callahan, 'Same-Sex Marriage: Why It Matters - At Least For Now' (2009) 24 Hypatia 70,77

${ }^{9}$ Stonewall, 'Remember! Remember! The $5^{\text {th }}$ of December!' (Winter 2005) Friends p.4

${ }^{10}$ Rosemary Auchmuty, 'Out of the Shadows: Feminist silence and liberal law' in Vanessa $E$ Munro and Carl Stychin (eds), Sexuality and Law: Feminist Engagements (RoutledgeCavendish 2007) 92
} 
homosexuality as a 'pretend family relationship'. This forced silence upon the mostlyfemale teachers, librarians and others in local-authority-funded venues; never prosecuted in England, it was only repealed in 2003. Many lesbian feminists who registered civil partnerships in the early days of the Act did so precisely because they wanted to be noticed, to show that they existed and presented good models of egalitarian relating - 'I wanted to be counted'. ${ }^{11}$ In the US, Kimberley Richman categorised these kinds of response as both 'Marriage as Validation' and 'Marriage as Protest'. In fulfilment of Cheshire Calhoun's contention that marriage was a necessary prerequisite for full citizenship, ${ }^{12}$ she concluded that the advent of same-sex marriage was, for lesbians and gay men, 'a marker of full citizenship and humanity' on a par with the right to vote. ${ }^{13}$

\section{FEMINIST CRITIQUES}

In these liberal times we sometimes need to be reminded how many people opposed the legal recognition of same-sex relationships and how that opposition was - and still is allowed to be expressed in offensive terms ranging from vitriol to pity. In such a context it has always been hard to strike a critical note without appearing to align oneself with the homophobic right or putting oneself at odds with those engaged in celebrating the achievement. This helps to explain the dearth of radical critical response in the lead-up to the Civil Partnership Act 2004. But there were other reasons for the silence. First, the legislation took most people by surprise. Lord Lester's private member's bill had included unmarried heterosexual couples, and the attempts to insert an even wider range of groups into the subsequent government bill were seen as homophobic in intent (as they mostly were), designed to deflect attention from the specific needs of lesbians and gay men. ${ }^{14}$ These various political manoeuvres had the effect of confusing the public so that in the end most people were not clear as to what the legislation actually did, a situation exacerbated by the length of the Act and the opacity of the legal wording. In truth, the vast majority had no idea that civil partnerships were essentially civil marriage for gays and lesbians - as Carl Stychin put it, 'a clear attempt to translate the entire package of rights and responsibilities,

\footnotetext{
${ }^{11}$ Rosie Harding, Regulating Sexuality: Legal consciousness in lesbian and gay lives (Routledge, 2011) Chapter 6; Auchmuty, n 7, 152, 157

${ }^{12}$ Cheshire Calhoun, Feminism, the Family, and the Politics of the Closet (OUP 2000)

${ }^{13}$ Kimberley D Richman, License to Wed (New York University Press 2014) 214

${ }^{14}$ Carl Stychin, 'Not (Quite) a Horse and Carriage: The Civil Partnership Act 2004' (2006) 14 Feminist Legal Studies 79, 80
} 
and benefits and detriments, of marriage into a same-sex context' ${ }^{15}$ Years later, when heterosexual couples made a bid for inclusion in the civil partnership regime, the commentary that appeared indicated that the public still doesn't realise that civil partnership is legally virtually the same as marriage. ${ }^{16}$

A second reason for the critical silence was that same-sex relationship recognition had not been high on most radical agendas and certainly not that of feminists. It took us unawares. There was nothing in the UK like the flood of campaigning literature generated in the US, and the Act itself was 'enacted with remarkably little controversy or fanfare' ${ }^{17}$ In particular, Stychin noted, there was no mention of the various feminist critiques of marriage in the parliamentary debates, even by female Labour MPs. ${ }^{18}$ Third, it was hard for lesbians and gay men to appear critical of a measure designed to give them equal rights, and even harder for heterosexuals to intervene, although heterosexuals knew the limitations of state regulation of their relationships better than anyone else.

The 'Invisibility of Feminist Voices in the Same Sex Marriage Debates' was remarked upon by Susan Boyd in the north American context and by other writers elsewhere. ${ }^{19}$ But feminist critiques did begin to appear, first focusing on the undesirability of the marriage model. These were met by other critiques defending relationship recognition and claiming a transformative potential. ${ }^{20}$ There were thus two quite distinct feminist reactions to samesex relationship recognition, both of which took the debate beyond the simple premises of equality and citizenship. Both groups of spokespeople, it is clear, felt defensive about their position, and neither was happy about dividing the feminist movement which was already so marginal and under attack. No wonder that scores of lesbian feminists simply took themselves off to register a civil partnership to avail themselves of the apparent legal protections, but kept largely silent about it, not concealing but not proclaiming the

\footnotetext{
15 ibid 79

${ }^{16}$ Guardian editorial 27 June 2018 and response by Rosemary Auchmuty in Letters to the editor, Guardian 2 July 2018

17 Stychin $\mathrm{n} 14,79$

18 ibid 81

${ }^{19}$ Claire Young and Susan Boyd, 'Losing the Feminist Voice? Debates on the Legal recognition of Same Sex Partnerships in Canada' (2006) 14 Feminist Legal Studies 213; Auchmuty n 10, 92; Boyd n 3, 280.

${ }^{20}$ Eg Nan D. Hunter, 'The Future Impact of Same-Sex Marriage: More Questions Than Answers' (2012) Georgetown Law Review 1055
} 
achievement either (in much the same way and for the same reasons as many heterosexual couples got married). These women (and some men) entered into civil partnerships and marriage not because they embraced the institution but because they thought the personal benefits to them outweighed the reservations they might have about it in principle - again, much as many married couples have done before them.

\section{The dangers of legal regulation}

'Not very long ago lesbians and gay men found themselves harshly regulated by criminal law,' observed Katherine Franke. ' ...Now we clamor to have the state regulate our romantic lives in a new way. You'd think we might have wanted a break from the state' ${ }^{21}$ The problem with legal regulation is that people have no choice about the form of that regulation, which, for couples accustomed to being outside the law and having to make their own arrangements, can be at best surprising and at worse quite negative. Franke remarked:

I've long felt that before the gay and lesbian community committed to a civil rights strategy based on "if-they've-got-it we want it too", we ought to take a close look at what "they" have before "we" insist on getting in on it'. ${ }^{22}$

To access equality and citizenship through marriage is particularly problematic for feminists. Franke concludes that the campaigns to admit same-sex couples served to reinvigorate what had been an outmoded and declining view of marriage as 'the most august holding environment for the elaboration of one's mature and authentic self, and one of the most fundamental institutions of a civilized society' - and with this, recharged its oppressive aspects and made life more difficult for those outside it. ${ }^{23}$ It is on divorce that the legal consequences of marriage become clearest. But 'for many same-sex couples, the rules of divorce are ill-suited to the structure, value and needs of their relationships'; they invite people 'to treat the rights and wrongs of a relationship as monetizable claims against one another'. ${ }^{24}$

\section{Marriage as a site of women's oppression}

\footnotetext{
${ }^{21}$ Katherine Franke, Wedlocked: the perils of marriage equality (New York University Press, 2015) 9

22 Ibid 7

${ }^{23}$ Ibid 61

${ }^{24}$ Ibid 20, 8
} 
Feminists have been critical of marriage as a site of women's oppression for at least 200 years. Under the common-law system of coverture, challenged and gradually dismantled through the efforts of first-wave feminists over the nineteenth century, married women's property passed to their husbands; husbands had sole custody of children; husbands could legally beat their wives and had free sexual access to them (this last until 1991!). At the same time, under the capitalist economy that emerged after the Industrial Revolution, women could neither vote nor hold public office; were denied higher education and skilled training; when permitted to work earned much less than men (and still do); were excluded by law or custom from paid employment after marriage or parenthood; and were expected to take full responsibility for the domestic sphere (which is to say that men were not expected to take any). Again, until challenged by feminists, women were given little legal protection from men's violence and sexual assaults and had difficulty accessing contraception and abortion. Until recently, men were the designated heads of households who, in controlling the purse strings, also effectively controlled their wives physically, materially and psychologically. This personal control was accepted and indeed facilitated by the patriarchal state, the two spheres - public and private - working together to ensure men's continued domination.

After many hard-won legal reforms, always instigated by feminists and generally achieved belatedly, grudgingly, and partially, marriage has become a much more benign and egalitarian state these days for most people. ${ }^{25}$ But that is not to say that the institution is entirely free of oppressive features. In spite of the abolition of enforced gender roles, the capitalist form of social organisation we currently enjoy continues to embody the expectation of such roles, and even couples who try to transcend them find this hard to achieve. When children arrive, or when one person's career progression requires the subordination of the other's, they almost always have to choose which party will be the principal breadwinner and which the principal homemaker. These roles are routinely mapped on to sex, so it is women who tend to be identified as needing 'family-friendly' policies at work, and women who are assumed to take the main responsibility for caring roles. Because of these expectations, they are discriminated against in the workplace.

\footnotetext{
${ }^{25}$ Rosemary Auchmuty, 'Law and the power of feminism: how marriage lost its power to oppress women' (2012) 20 Feminist Legal Studies 71
} 
Earning less than men, and cheaper than paid-for childcare, they end up forced into economic dependence on a husband even when that was never the couple's intention; and the motivations that put them in this place are portrayed in liberal terms as personal choice rather than structural necessity.

Marriage has also long been recognised as a site of physical danger for women. Though less tolerated today than in the past, it remains so.

For every good story of those who live happily together for twenty-five years or more, it is possible to produce other stories of those irreversibly injured or murdered by a spouse or driven to kill in self-defense. ${ }^{26}$

Of course, couples do not have to be married to be placed in this situation; indeed, lesbian feminists pointed out 30 years ago that it was heterosexuality, rather than marriage, that was the real agent of private patriarchal oppression for women. But marriage both symbolises and reinforces the gendered expectations that give rise to women's subordination and so its effects are felt by those outside the institution as well as those within.

It is unarguable that husbands' abuse of their wives is less routine and is now taken more seriously, largely because feminists fought to put it on political agendas, but also because women now have more choice about whether to enter into marriage or not. Until first-wave feminists achieved educational improvements and carved out employment options in the nineteenth century, marriage was the only respectable career for women, and often their only means of subsistence. ${ }^{27}$ In the mid-twentieth century, social pressure performed the same function of forcing women into marriage at any cost, because the stigma of spinsterhood - of being 'left on the shelf' - was so great, and the chances of earning enough to live comfortably were so limited. Again, only as a result of feminist campaigns for educational and work opportunities, equal pay and access to contraception and abortion could acceptable alternatives to marriage be created and the pressure taken off women to rush into marriage. ${ }^{28}$ Nevertheless, as Franke explains,

\footnotetext{
${ }^{26}$ Card n 2, 28

${ }^{27}$ Rosemary Auchmuty, 'Marriage and Civil Partnership: Law's role, feminism's response' in Margaret Davies and Vanessa E Munro (eds), The Ashgate Research Companion to Feminist Legal Theory (Ashgate 2013) 285-90

${ }^{28}$ Auchmuty $\mathrm{n} 19$
} 
too much of many women's well-being and flourishing remains tied up with their ability to marry well (economically, that is), and marry good (to a kind man, that is). Living outside of marriage (never marrying, divorcing, or living as a widow) continues to be a precarious place for far too many women. ${ }^{29}$

This can make women reluctant (or even unable) to leave abusive relationships.

If through the assimilation of lesbian and gay couples marriage becomes more and more the norm and expectation, the choice of not to do so may become a more difficult one to make. Now the question 'Why don't you get married?', constantly addressed to young women in my youth and more recently aimed by family lawyers at unmarried cohabitants, ${ }^{30}$ will be - and is being - extended to lesbians and gay men, who will feel the same insidious pressure to conform.

For all these reasons - its ignominious history, its patriarchal associations, its very raison d'etre as an instrument of conformity - many feminists find the idea of marriage as a liberationary goal a contradiction in terms. Such a response was summed up in Paula L. Ettelbrick's brilliant essay 'Since when is marriage a path to liberation?', published in 1989 at the inception of the movement, the one critical feminist response most frequently encountered and reproduced in American collections, often standing alone and isolated in collections replete with positive arguments by men and negative statements by religious conservatives. ${ }^{31}$ More recently, many in the UK have echoed this comment. 'To see this hollow institution as desirable is laughable,' wrote Dea Birkett in response to the Civil Partnership Act in 2004. ${ }^{32}$ And Suzanne Moore greeted the Marriage (Same Sex Couples) Act 2013 with the comment,

Equal rights to monotony, monogamy and vol-au-vents is just not my idea of modernisation or equality, because marriage is not an institution based on equality. ... I don't begrudge anyone their right to join this club. But why would they want to ? $^{33}$

\footnotetext{
${ }^{29}$ Franke n 21, 51

${ }^{30}$ Anne Barlow and Janet Smithson, "Legal assumptions, cohabitants' talk and the rocky road to reform' (2010) 15 Child and Family Law Quarterly 335-6; Simon Duncan, Anne Barlow and Grace James, 'Why don't they marry? Commitment and cohabitation in $21^{\text {st }}$ century Britain' (2012) 17 Child and Family Law Quarterly 383-398

${ }^{31}$ For example, in Sullivan ed. Same-Sex Marriage: Pro and Con, n 5, at 118; Baird and Rosenbaum, n 5, at 164

32 Guardian 4 Oct 2004

${ }^{33}$ Suzanne Moore, 'What the Tories are pushing is conformity. If marriage is the goal, then don't pretend that it is a vehicle of equality'. Guardian 7 Feb 2013
} 


\section{Marriage as site of couple privilege}

A second, equally fundamental feminist critique of marriage, and thus of the form of samesex recognition offered in the UK, is that it privileges the couple. The most complete British argument against same-sex marriage for this reason is Nicola Barker's Not the Marrying Kind: A feminist critique of same-sex marriage (Palgrave Macmillan, 2012), which concludes with a powerful argument to move the law 'beyond conjugality'. Carol Smart (amongst others) levelled this accusation at marriage more than 30 years ago in her influential study, The Ties That Bind, ${ }^{34}$ where she noted that it left stranded those who, for whatever reason, were not in couple relationships - the single, widowed, divorced, people living with (and often caring for) family members. ${ }^{35}$ But this criticism takes on a particular significance in the light of subsequent lesbian and gay history because same-sex marriage also does nothing to help any of the other family forms that lesbians and gay men developed, particularly in the 1980s in the shadow of AIDS and section 28 - what were called 'families we choose' ${ }^{36}$ The Civil Partnership and Marriage (Same Sex Couples) Acts are 'me-too' measures; nice for those who fit into the limited template, bad luck for those who do not! They absorb potentially dissonant parties into the mainstream, leaving alternatives unappreciated and without public support, even though their needs may be greater. Worse still, they reward those who, though once excluded from marriage, are nevertheless privileged - those who have partners, who are loved and supported and have someone to share their personal and financial burdens. As Katherine Franke puts it, 'Gaining the right to marry risks bringing it with it the expectation that all in the community conform to traditional notions of coupling, and can have the unintended consequence of making the lives of lesbians and gay people who aren't in traditional relationships more precarious, not less'.$^{37}$

It is ironic that the attempts by parliamentary conservatives to widen the Civil Partnership Act 2004 to encompass other domestic relationships, thought intended to

\footnotetext{
${ }^{34}$ Routledge and Kegan Paul 1984

${ }^{35}$ For a summary of second-waves critiques, see Rosemary Auchmuty, 'What's So Special About Marriage? The impact of Wilkinson v Kitzinger (2008) 12 Child and Family Law Quarterly 491-495; Auchmuty n 25, 291-293

36 Jeff Weeks, Brian Heaphy and Catherine Donovan, Same-Sex Intimacies: Families of Choice and Other Life Experiences (Routledge 2001)

${ }^{37}$ Franke n 21, 15
} 
deflect attention from lesbian and gay claims, in fact mirrored feminist concerns over the legislation's assertion of the primacy of the conjugal couple. Carl Stychin quotes the protest by Christopher Chope $\mathrm{MP}^{38}$ that the Civil Partnership Act would be 'an insult to all those who happily share their lives with relatives or friends outside marriage, because their relationships will be given institutional inferiority to homosexual ones' ${ }^{39}$

One of the government's aims in introducing the civil partnership legislation was to change the public perception of homosexuality implicit in Chope's comment, and one way to do that, they surmised, was to encourage gay men in particular (lesbians were, as usual, invisible in the debates) away from the kinds of anti-social behaviours for which they were noted (promiscuity, public sex) - and into conformity with social norms: to 'domesticate' them, as Carl Stychin put it. ${ }^{40}$ This was a conservative goal, as Prime Minister Cameron admitted at the Tory party conference in 2011: 'I don't support gay marriage despite being a Conservative. I support gay marriage because I am a Conservative'.$^{41}$ But to earn public acceptance, all alternative ways of relating had to be de-legitimised or, better still, closed off.

There is some evidence that, in this, the legislation has have been successful. The alternative support arrangements that gay men and lesbians evolved during the eras of illegality and the AIDS crisis, which transcended conjugal and familial ties, persisted for some time afterwards. ${ }^{42}$ Alison Rolph and Elizabeth Peel, in an empirical study published in 2011, found that, for all the couples who entered into civil partnerships in the UK, there were others who rejected 'assimilation into heteronormative cultural frameworks'. ${ }^{43}$ But later research suggests that younger lesbians and gay men have largely replaced the networks of 'families we choose' by normative (gendered) expectations of care being

\footnotetext{
${ }^{38}$ Notoriously many years later for being the lone voice that stopped the progress of a bill to criminalise the practice of 'upskirting' .

${ }^{39}$ Hansard, Commons, 2 October 2004, p.213, quoted Stychin n 14, 81

${ }^{40}$ Stychin $\mathrm{n} 14,83$

${ }^{41}$ Quoted by Suzanne Moore, 'The only way is marriage?' Guardian 15 Oct 2011

${ }^{42}$ Sasha Roseneil and Shelley Budgeon, "Cultures of Intimacy and Care Beyond "the Family": Personal life and social change in the early $21^{\text {st }}$ century' (2004) 52 Current Sociology 135 , 142

43 Alison Rolph and Elizabeth Peel, "'It's a Double-Edged Thing": the paradox of civil partnerships and why some couples are choosing not to have one' (2011) 21 Feminism \& Psychology 317
} 
located within the couple and the now-accepting family of origin. ${ }^{44}$ As the collective memory of these alternative ways of relating die out, younger generations of the gay and lesbian community may find themselves having to reinvent them when they experience the constraints of the conjugal relationship or find themselves excluded from it.

A second feminist criticism of the privileging of the couple status is that it is wrong in principle that benefits should accrue through relationships rather than on an individual basis. In the US Nancy Polikoff consistently over two decades has voiced an anti-marriage viewpoint. In addition to arguing that marriage only benefits heteronormative couples and ignores the huge variety of family forms developed by heterosexuals as well as gays and lesbians, she demonstrates that no one should have to marry to get basic social and economic rights since those rights could be within the reach of all individuals and families. ${ }^{45}$

In the UK our right to healthcare is an individual one but other rights are reserved to the registered couple: the privilege of passing your property to your partner and children free of tax (if you happen to be rich enough to be liable for inheritance tax, which most of us are not) or to inherit automatically from your deceased partner if s/he did not make a will (the rest of us will have to make a formal claim - or, better still, ensure that wills are made). These privileges exist expressly to support marriage, which means that a decision to enter into a civil partnership or get married is not simply a personal one, it helps to disadvantage those who do not or cannot conform. It nips in the bud what in the last decades of the twentieth century had seemed a promising movement towards the acceptance of unmarried cohabitation with measures such as the removal of the stigma of illegitimacy for children of unmarried parents. ${ }^{46}$ 'I have thought,' concludes Lisa Duggan sadly, 'we would want to diversify and democratize the ways we recognize dependencies rather than enshrine the right to marry as a priority goal'. ${ }^{47}$

\section{Marriage privatises care}

\footnotetext{
${ }^{44}$ Brian Heaphy, Carol Smart and Anna Einarsdottir, Same-Sex Marriages: New Generations, New Relationships (Palgrave Macmillan 2013)

${ }^{45}$ Nancy Polikoff, Beyond (Straight and Gay) Marriage: Valuing all families under the law (Beacon Press, 2008)

46 In England under the Family Reform Act 1987

${ }^{47}$ Lisa Duggan, 'Beyond Same-Sex Marriage' (2008) 9 Studies in Gender and Sexuality 155, 156
} 
Prior to the coming into force of the Civil Partnership Act in December 2005, same-sex couples living together were treated as individuals for the purposes of welfare benefit allocation. Once the Act was in force, benefits for same-sex couples were assessed on a household basis, whether the parties had registered a civil partnership or not. The consequence was that the benefit entitlement of many couples was reduced because it was based on their aggregated means, on the basis that the better-off partner would support the other.

This brought same-sex couples into line with unmarried heterosexual couples, whose benefits had been assessed on a household basis since 1966. While fair in one sense - why should same-sex couples be treated more generously than heterosexuals? - it was unforeseen. It had never occurred to campaigners that they might be worse off as a consequence of the reform, still less that it should affect even those who were opposed to the law. Feminists did not fail to note that the gainers from this legislation were mostly men who, having enjoyed higher incomes all their lives, and often childless, owned expensive properties and assets that would have made them liable to inheritance tax, which they were now spared. The losers, on the other hand, were mostly women, who generally earned less, especially if they had children, and who might lose part of their already pitiful benefit income and end up even poorer.

This story raised two important points for feminists. First, it showed how the relationship recognition legislation, by aligning same-sex with heterosexual couples, had both levelling up and levelling down effects that had potential impact on all lesbians and gay men. Second, it reinforced a state policy that feminists had long criticised: the privatisation of care responsibilities within the family. By drawing same-sex couples into the family net, it reduced the welfare 'burden' to the state by locating it within the couple and ensured that any financial hardship that resulted from care work became first and foremost a private matter.

Feminists have long argued that care should be a public responsibility. Children are everyone's future - the very continuance of society depends on their nurture - while elders should be looked after in recognition of lifetimes of service. Feminists also recognise that the association of women with children and the caring role generally has been one of the principal ways the patriarchal state keeps women poor. One of the first four demands of the Women's Liberation Movement in 1970 was for 24-hour nurseries, not so that children 
could be abandoned for 24 hours but so that women would not be denied the possibility of paid employment because their childcare obligations did not fit with occupational demands. Because public childcare provision is limited, and private facilities expensive, it is usually cheaper for care to be undertaken in the family. This is turn means that couples with children will have to make the 'choice' of who gives up work or goes part-time to do this work. Within the heterosexual couple this will usually be the woman, but with the same-sex couple, one of the partners will have to take on this gendered role. As Canadian Susan Boyd points out, 'Capitalism benefits regardless of the sex of the couple, but the consequence is that the caregiver becomes economically dependent on their partner'. ${ }^{48}$ In a survey of lesbians' and gay men's attitudes to the introduction of civil partnerships in the UK, Rosie Harding found a clear awareness among some of her interviewees of 'feminist objections to marriage and the privatization of economic responsibility'. ${ }^{49}$

\section{Marriage takes attention from more important issues}

A final criticism posits that gays and lesbians should not be putting their energies into campaigning for marriage protection when they could be focusing on measures intended to improve the lot of all people, such as universal access to healthcare or pension rights.

Katherine Franke, for example, warns of elevating liberal gain above the more threatening but more vital rights for subordinate groups - for example, reproductive rights for women. Indeed, she points out, the marriage rights campaign actively worked against the possibility of strengthening other legal forms of protection for one's loved ones, such as powers of attorney. ${ }^{50}$ Neverthless Franke argued that marriage should be available to same-sex couples who wanted it.

In contrast, Claudia Card was not interested in reluctantly supporting the movement for same-sex marriage as a short-term goal while additionally working for more fundamental changes; rather, she thought that marriage should be off the agenda altogether. ${ }^{51}$ For Card, acceptance of marriage meant propping up an institution which perpetuated injustice and inequality; thus, pursuing it was not adopting one strategy out of many, it was adopting a strategy that positively stood in the way of real substantial reform:

\footnotetext{
${ }^{48}$ Boyd n 3, 276

${ }^{49}$ Rosie Harding, 'Recognizing (and Resisting) Regulation: Attitudes to the introduction of civil partnership' (2008) 11 Sexualities 740, at 758.

${ }^{50}$ Franke n 21, 106

${ }^{51}$ Card n 2, 32
} 
'My ideal is that the law not define or in any other way regulate durable intimate unions between freely consenting adults' ${ }^{52}$

Many feminists share Card's view that marriage should be de-centred in favour of more important goals and options. ${ }^{53}$ Martha Fineman, for example, would remove legal protection from conjugal couples and give it instead to caregiving roles such as mother and child. ${ }^{54}$ To these utopian (as they see them) suggestions, other feminists have responded angrily. 'Abolishing the institution of marriage is a long, long way off,' Joan Callahan pointed out. 'In the meantime, the institution harbors crucial rights and goods not available to some people ...' ${ }^{55}$ But this is precisely Card's point: even when same-sex marriage is won, those rights and goods will still only be available to 'some people'. Many whose needs are just as great will miss out.

Still other feminists have given attention to how many of the rights and benefits promised by civil partnership and same-sex marriage can be obtained through other means, and have indeed been acquired by lesbian and gay couples who inform themselves as to the relevant law and order their lives accordingly. In the US, Nancy Polikoff set out a comprehensive list of legal protections that can be accessed in ways other than through marriage.$^{56}$ In the UK it was noted that, prior to the partnership recognition legislation, lesbian and gay couples were much more likely than unmarried heterosexual cohabitants to have made wills and put their home in joint names, ${ }^{57}$ being under no illusion (as some heterosexuals were) that they would be protected by a 'common-law marriage'. In other words, lesbian and gay couples were less likely to need the legal 'protections' of marriage because they had already protected themselves in other legal ways.

Finally, anti-marriage feminists point out that allowing lesbians and gay men to marry will not eliminate homophobia and heterosexism. ${ }^{58}$ We would be better off, they say,

\footnotetext{
52 ibid 27

53 e.g. Duggan n 47, 156

${ }^{54}$ Martha Albertson Fineman, The Neutered Mother, the Sexual Family, and Other Family Tragedies. Psychology Press 1995

${ }^{55}$ Callahan n 5, 78

56 Polikoff $n 45$

${ }^{57}$ Morgan Centre for the Study of Relationships and Person Life, Gay and Lesbian 'Marriage': an exploration of the meanings and significance of legitimating same-sex relationships (University of Manchester Press 2006) 1

${ }^{58}$ Young and Boyd n 17, 231
} 
keeping up our radical protests against the real hardships and dangers faced by lesbians and gay men in intolerant communities throughout the world, including on our own shores. In the UK, Julie Bindel wondered whether the prize of same-sex marriage was offered

as a clever ploy to keep us quiet about the trickier issues such as the deportation of lesbian asylum seekers, and the still prevalent anti-gay bullying in schools and religious communities? While so many lesbians are getting hitched and drawing up wedding lists, ... have we lost sight of those within our community suffering in silence ${ }^{59}$

To such criticisms, Mary Bernstein retorts that marriage isn't meant to solve all our problems: 'World peace tomorrow; same-sex marriage today'. ${ }^{60}$

\section{Same-sex marriage as 'better'}

I turn now from the negative feminist responses to same-sex marriage to the positive ones.

The first is the claim that same-sex marriage will be different from patriarchal marriage, indeed better, because it means something different. This view is variously expressed in terms of same-sex relationships being stronger because they have been so long in coming and forged in homophobic adversity ('It's something I never thought l'd be able to do', 61 because they are intrinsically more egalitarian ('With us, it's equal, equal, equal', ${ }^{62}$ and because gender-specific roles cannot be mapped on to same-sex couples ('it's not just shoring up the patriarchy'. ${ }^{63}$ Gay male marriages, we are promised, will show men in a different light - not only challenging the association of gay men with promiscuity, but modelling men as homemakers and carers. Lesbian couples will be free of the controlling hand of the husband; as one woman told Zoe Williams,

A lot of us old feminists had reservations about some of this baggage that goes with marriage. But this feels very natural and logical and 'phew, thank God we have at last got there' ${ }^{64}$

So, Zoe Williams concludes enthusiastically, 'still not equal. Better. ${ }^{65}$

\footnotetext{
${ }^{59}$ Julie Bindel, 'Gay marriage is not about equality but a way of keeping women quiet' Guardian 16 June 2014

${ }^{60}$ Mary Bernstein, 'Same-sex Marriage and the Future of the LGBT Movement' (2015) 29 Gender and Society 321

${ }^{61}$ Zoe Williams, 'Today's lawfully wedded couples fought for equality - but they have something better'. Guardian 25 Mar 2014

62 Zoe Williams, 'With us, it's equal, equal, equal'. Guardian 20 Sept 2014

${ }^{63}$ Williams n 61

64 ibid

65 ibid
} 
Before the advent of same-sex relationship recognition, there was some evidence that same-sex relationships were indeed more egalitarian in terms of roles and sharing. ${ }^{66}$ But this quality tended to diminish when there were children in the relationship or where there were substantial differences of earning capacity. ${ }^{67}$ In the UK there was also evidence that the dissolution rate of civil partnerships was lower than the divorce rate for marriages of similar duration, suggesting that same-sex relationships were more durable. ${ }^{68}$ But samesex divorce is increasing (particularly among women), while opposite-sex divorce seems to be on the decline, so it is difficult to substantiate any such claims for the future. ${ }^{69} \mathrm{My}$ prediction once same-sex marriages become more common and collective memory of shared oppression is replaced by absorption into the values of conventional marriage, divorce rates will converge.

That said, interviews with couples who had dissolved their civil partnerships revealed that many found that their confident expectations of 'better' relationships were disappointed. The reality did not match the hopes and dreams, and the ending of what were often relationships of quite long duration came as a shock. ${ }^{70}$ More problematically, early evidence showed that courts were not inclined to view same-sex relationships as 'different', and strove to impose conventional marital roles on couples in dissolution proceedings. ${ }^{71}$ A survey of younger civil partners indicated, meanwhile, that as a group they held much more conventional ideas about marriage and there was little evidence that their relationships were going to turn out any differently from those of their opposite-sex peers. ${ }^{72}$ Charlotte Bendall warns:

${ }^{66}$ Gillian Dunne, Lesbian Lifestyles: Women's work and the politics of sexuality (Macmillan 1997); Jeffrey Weeks, Brian Heaphy and Catherine Donovan, Same-Sex Intimacies: Families of Choice and other life experiments (Routledge, 2001)

${ }^{67}$ Christopher Carrington, No Place Like Home: Relationships and family life among lesbians and gay men (University of Chicago Press, 1999); Robert Leckey, 'Must Equal Mean Identical? Same-sex couples and marriage' (2014) 10 International Journal of Law in Context 5 , at 11

${ }^{68}$ Auchmuty $n$ 4, 213

69 Office for National Statistics, Divorces in England and Wales: 2017. https://www.ons.gov.uk/peoplepopulationandcommunity/birthsdeathsandmarriages/divor ce/bulletins/divorcesinenglandandwales/2017, accessed 6 December 2018

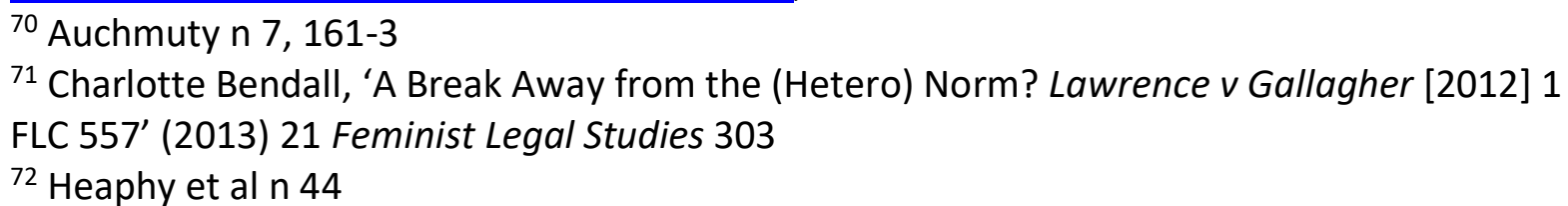


The current state of the law might be considered objectionable on the basis that, in consistently drawing upon notions of the traditional gender binary, the courts are ultimately helping to reproduce patterns of expected roles'.$^{73}$

Finally, we cannot deny the huge shifts that have taken place over the past few decades in the ways opposite-sex marriages are actually experienced. Many more wives are breadwinners, more husbands share housework and childcare (up to a point). But how much of this is due to the positive model of same-sex relationships, and how much to the efforts of heterosexual feminists and supportive men to challenge gender-role norms and make their relationships more egalitarian, is a moot point. It is quite possible that it is the latter group who should take most of the credit for tidying up marriage so that it became more open and relaxed and such an attractive model for gays and lesbians to wish to enter. 'In this sense,' Franke concludes, 'permitting same-sex couples to marry may be more of a symptom than a cause of this evolution' ${ }^{74}$

\section{Marriage as transformative}

Building on the contention that same-sex marriages have the potential to be better than opposite-sex marriages, some feminists contend, further, that same-sex marriage could have a transformative effect on the institution of marriage generally. In the US, Nan Hunter was an early feminist advocate of the potential of same-sex marriage to destabilise gender systems. ${ }^{75}$ In the UK, Rosie Harding agreed:

Once marriage becomes a formal relationship between two persons (rather than 'one man and one woman') the place of gender roles (wife/husband; mother/father) within the family are [sic] necessarily disrupted. As such, same sex marriage has the potential to have wide-ranging transformative effects on gendered relations within marriage, and therefore to be as much for the benefit of heterosexual women (through the dismantling of gender norms within marriage) as for lesbians and gay men. ${ }^{76}$

This argument rests on the reasoning that the very definition of marriage must change as we see more and more couplings where gender roles cannot be mapped directly on to sex-

\footnotetext{
${ }^{73}$ Charlotte Bendall, 'Some are more "Equal" than Others: heteronormativity in the postWhite era of financial remedies' (2014) 36 Journal of Social Welfare and Family Law 260, at 261

${ }^{74}$ Franke n 21, 154

${ }^{75}$ Nan D. Hunter, 'Marriage, Law and Gender: a feminist inquiry' (1991) 1 Law and Sexuality

${ }^{76}$ Rosie Harding, 'Sir Mark Potter and the Protection of the Traditional Family: Why same sex marriage is (still) a feminist issue' (2007) 15 Feminist Legal Studies 223, 232
} 
where we can no longer assume that a husband will be the main earner and a wife the homemaker - so that marriage can no longer be seen as a form of social organisation in which men control women. Harding concludes that the legal regulation of same-sex relationships 'does not necessarily have to work on lesbians and gay men in the same way as marriage does on individuals within heterosexual culture ... space can be created within the disciplinary mechanisms of power for alternative ways of living' ${ }^{77}$ Likewise, Mary Bernstein in the US contends that same-sex marriage challenges the dominant heterosexual model and possibly the expectation of monogamy and, at the very least, generates public policy debates and shifts. ${ }^{78}$

This last is undoubtedly true. All anti-marriage critics have had to tackle the argument that same-sex marriage will lead to the 'elimination of enforced sex roles,' as Mary Anne Case puts it. ${ }^{79}$ In general, however, they are unconvinced. As heterosexual couples who have tried to transcend gender roles within their own relationships have all too often found, the external weight of legal, social and economic forces is very hard to resist, let alone influence. Couples may swap roles, but 'the institution of marriage at a macro level still embodies patriarchal and heterosexual norms' ${ }^{80}$ As Jyl Josephson explains, 'Statesanctioned marriage is a public institution and the state, not the parties who enter into it, determines the terms of the marriage contract' ${ }^{81}$ She notes, as British commentators have also found, that most couples who enter into marriage are vague about the actual law of marriage (or civil partnership): 'newly married couples receive a marriage certificate, but not a copy of the marital relations code' ${ }^{82}$ For early American critics like Paula Ettelbrick, ${ }^{83}$ Nancy Polikoff ${ }^{84}$ and Ruthann Robson, ${ }^{85}$ 'there is no way for lesbians to avoid being

\footnotetext{
77 Harding n 11, 123, 130.

78 Bernstein $\mathrm{n} 60$

${ }^{79}$ Mary Anne Case, 'What Feminists Have to Lose in Same-Sex Marriage Litigation' (2010) 57 UCLA Law Review 1199

${ }^{80}$ Boyd n 3, 277

81 Jyl Josephson, 'Citizenship, Same-Sex Marriage, and Feminist Critiques of Marriage' (2005)

3 Perspectives on Politics 269, 271

82 ibid

83 n 31

${ }^{84} \mathrm{n} 45$

${ }^{85}$ Ruthann Robson, 'Assimilation, Marriage, and Lesbian Liberation' (2002) 75 Temple Law Review 709
} 
colonized by the institution and its normalizing tendencies' ${ }^{86}$ And this, of course, is what conservative advocates of same-sex marriage like David Cameron hoped for: they wanted 'marriage to change queers, not queers to change marriage'.${ }^{87}$

A second problem with the transformation claim is that, in order to win recognition of their relationships, many advocates felt they had (or actually wanted) to represent their relationships as just like everyone else's. In so doing, they undercut the radical claims of other same-sex couples by appearing to accept uncritically the gendered roles of heterosexual marriage. Susan Boyd quotes a witness to the Canadian parliamentary committee considering legal recognition of same-sex relationships who pleaded:

I come to you as a traditional lesbian, who's been together for 19 years and has children. My partner is quitting work in a couple of weeks so she can stay home with our children. We need to be recognized for our equality with other couples who make choices. 88

The choice this couple is making is a gendered one, the witness becoming breadwinner and her partner homemaker. They may both be women but their decision has done nothing to challenge the gendered norms of marriage; indeed, it can only reinforce them. It comes as no surprise then that many advocates of same-sex marriage did so on the ground that would strengthen rather than threaten traditional marriage.

In the UK, when feminists Sue Wilkinson and Celia Kitzinger sought legal recognition of their Canadian marriage as a marriage in this country, they carefully avoided representing it in terms of gendered roles (which were not a feature of their relationship). Nevertheless they felt it necessary to make some sameness arguments: Wilkinson was quoted as saying,

I want to be able to refer to Celia as my wife and have that immediately and unproblematically understood as meaning that she is my life-partner with all the connotations and social consequences that using the term 'wife' or 'husband' has for a heterosexual couple. ${ }^{89}$

The irony of this declaration was not lost on those feminists who had subscribed to the 'Why Be a Wife?' campaign 20 years before. Gill Butler's article with that title appeared in May 1996 in the newsletter of the lesbian and gay legal lobby group Stonewall, ${ }^{90}$ whose

\footnotetext{
${ }^{86}$ Josephson $\mathrm{n} 81,274$

87 ibid

${ }^{88}$ Boyd n 3, 282

${ }^{89}$ Wilkinson v Kitzinger [2006] EWHC 2022, para.5

90 Stonewall Newsletter 4, May 1996; see also Bindel n 59
} 
publicity for same-sex marriage 25 years took a very different tone: 'People are people. Marriage is marriage.' 91

In 2013, as same-sex marriage was being introduced, Julie Bindel undertook a survey of almost 10,000 people's reasons for wanting to marry. 89 per cent of her respondents, homosexual and heterosexual, male and female, supported 'equal marriage'. Reporting her findings, Bindel posed the rhetorical question 'lesbian marriage somehow subverts the heterosexual - but does it?', observing in answer that

many gay respondents have a desire for 'ordinariness' and do not want to be seen as living 'alternative lifestyles'; they looked forward to being viewed as 'the same' as heterosexuals. ${ }^{92}$

Certainly Zoe Williams's endorsement of same-sex marriage in the Guardian gives this impression. One of her articles, illustrated by a picture of a white nuclear family (two parents, who just happen to be women, and two children), included statements from a lesbian about her relationship: 'Life is just normal. Being gay is just normal. Sometimes I have to watch TV to remember that people have a problem' ${ }^{93}$

\section{CONCLUSION}

Who would have predicted that the next stage in this saga in the UK would be that heterosexual couples in the UK would demand the right to have a civil partnership rather than a marriage? Who would have imagined that the civil partnership, once dismissed as 'second-best', a 'consolation prize' by those who sought the 'gold standard' of marriage, ${ }^{94}$ would be transformed into an object of desire? Yet we should have foreseen this, because the idea that lesbians and gay men might have a choice that is not available to the dominant heterosexual majority represents a challenge to the natural order - it must be reversed! Once again, equality and non-discrimination arguments have been mustered to declare the injustice of heterosexual exclusion from an institution which, no one seems to mention (or possibly realise), remains legally so similar to marriage that early homosexual adopters often used the language of marriage (wedding, wife, husband) when describing their own. ${ }^{95}$

\footnotetext{
${ }^{91}$ Stonewall postcard, nd.

92 Bindel $n 59$

93 Williams n 62

${ }^{94}$ Wilkinson v Kitzinger, para. 6

${ }^{95}$ Auchmuty n 4, 208
} 
This is not the place to present a feminist analysis of the probable extension of civil partnership to heterosexual couples. But it seems a fitting point on which to end this survey of feminist responses to same-sex relationship recognition. The shift in attention back to heterosexual grievance has opened the way to increased criticism of marriage as an institution, criticism that has been sympathetically received in the courts. ${ }^{96}$ For feminists this can only be good, contributing (we hope) to the declining influence of traditional marriage and to more egalitarian couple relationships. For this reason it can be welcomed. But there are also many reasons for feminists to be critical of this new development. In what sense can heterosexuals be said to suffer a loss of respect and dignity because they can't have a civil partnership while lesbians and gay men can? Their suffering is as nothing compared to the assaults on their dignity that lesbians and gay men endured for centuries. The claimant couple's success this case demonstrate how easily equality and nondiscrimination arguments can be appropriated by dominant groups, and human rights lose their true meaning.

${ }^{96}$ [2017] 3 WLR R (Steinfeld) v Education Secretary (CA), overturned in the SC 27 Jun 2018 